$\xi=-1$

\title{
Characteristics of Startup Company and Its Strategy: Analysis of Indonesia Fashion Startup Companies
}

\author{
Rahmat Nurcahyo $^{1 *}$, Mohammad Ilhamsyah Akbar ${ }^{1}$, Djoko Sihono Gabriel ${ }^{1}$ \\ ${ }^{1}$ Department of Industrial Engineering Universitas Indonesia Depok, 1624, Indonesia \\ *Corresponding author E-mail: rahmat@eng.ui.ac.id
}

\begin{abstract}
Startup companies, as an organization in the early phase, have different characteristics than mature organization. The research method is qualitative because the purpose is trying to understand the startup characteristics. The research object is Indonesia fashion startup companies because it is one of the most promising start ups in Indonesia. Strategy choices are crucial in fashion startups in Indonesia. Objective of this paper is to analyze the strategy that has been used in fashion startups in Indonesia. Most of the startups use intuitive decision making. The result is most fashion startups tend to use intensive strategy because the market is still growing. Intensive market penetration through marketing strategy and related diversification are the two strategies that commonly used in fashion startups in Indonesia.
\end{abstract}

Keywords: Fashion, Startup, Strategy, Intensive Strategy.

\section{Introduction}

An organization has its own life cycle during its existence. In general, the organization life cycle consist of four phase: start up, emerging growth, maturity, and revival [1]. Start up company is a company in the early stages of its operation [2]. Starts up company try to enter an existing market or sometimes open up a new market with innovative products or services [3]. Start ups are critical to the economics of a nation [4] including Indonesia. One of the most promising start ups business in Indonesia is fashion industry. Indonesian Creative Economy Agency stated that in 2015 the fashion industry is the second-largest creative industry in Indonesia [5]. Indonesia fashion industry has a promising market for the new entrants because the large number of the market. Fashion industry must always cater to the mass market that growing in expectation [6]. Fashion industry is a dynamic business, characterized by demand uncertainty resulting from the high variation of style and consumer tastes [7]. One of the most critical factors for a fashion company is the strategy because the viability of a fashion brand is dependent upon the efficacy and appropriateness of the decision of those responsible [8] Despite its significance, research on the theories of the firm mostly focusing on mature or established firm and the research on the new firm (such as start up company) has been neglected in the theoretical literature [9]. Strategic management is a crucial issue for start ups [10] because start up companies have characteristics that make them different from mature companies, such as the decision making process. The decision making process in start up company is usually intuitive and centralized [11]. The focus of strategic making process in start up companies is to expand the market while the focus of mature companies is the profit. Our preliminary research show that none of the objects using formal strategic management tools in strategy making process. Therefore this paper is purposed to list and analyze the strategy that has been used in male fashion start up in
Indonesia. This paper could be useful for new entrants in fashion business in Indonesia.

\section{Literature review}

The specification of patterns and its use in demonstrating the behavior of compressed /uncompressed data, and a way of utilizing this concept towards examining the appeal of compressibility.

\subsection{Characteristics of start up company}

Start up company is the organization in its earlier phase. This kind of organization has some characteristics; those characteristics are enlisted in table II.

Based on startup characteristics on literature [12][13][14][15][16], we classify those characteristics into 4 dimension: Organization (the character of the start up organization), Ownership (characteristics of owner, decision making, and supervision), Strategy and Innovation, and Financial. These list are built up from the previous literature, the similar characteristics are grouped as one.

Table 1: Start Up Characteristics [12, 13, 14, 15, 16]

\begin{tabular}{|c|c|}
\hline \multicolumn{1}{|c}{ Table 1: Start Up Characteristics $[12,13,14,15,16]$} \\
\hline Dimension & Characteristics \\
\hline Organization & Small scale organization \\
\cline { 2 - 2 } & Young age \\
\cline { 2 - 2 } & Homogeny environment \\
\cline { 2 - 2 } & Informal structure \\
\cline { 2 - 2 } & Few differentiation \\
\hline \multirow{4}{*}{ Ownership } & Centralized \\
\cline { 2 - 2 } & Owner-manager \\
\cline { 2 - 2 } & Intuitive decision making \\
\hline Strategy \& Innovation & Direct supervision \\
\cline { 2 - 2 } & Niche marketing strategy \\
\cline { 2 - 2 } & Prefer risky decision than the secure one \\
\cline { 2 - 2 } & Fast innovation \\
\cline { 2 - 2 } & First mover or second mover \\
\cline { 2 - 2 } & Lack of product research \\
\hline Financial & Funding from personal savings or from relative \\
\hline
\end{tabular}

Copyright $\odot 2018$ Authors. This is an open access article distributed under the Creative Commons Attribution License, which permits unrestricted use, distribution, and reproduction in any medium, provided the original work is properly cited. 
Most of start up organizations is organic organization with high centralization [17], thus provide flexibility in decision making and quiet adaptive. Most start up has simple organization structure [18]. Simple organization structure has many characteristics, such as low departmentalization, wide span of control, centralized authority and low formalization [19]. Most start ups owner are also the manager of the company that make decision making. Ref. [20] classified start up into four class of owner manager. In decision making start up is characterized by intuitive decision making. Startups sometimes has established competitor thus they prefer specialist or niche marketing [21]. Start ups have high rate of innovation and prefer first mover strategy [22]. Start ups are mostly funded by personal savings or from relative [23]. Other option is use bootstrap financing, a method of funding with modest personal funds [24].

\subsection{Strategy}

Strategy is determination of the basic long term goals of an enterprise [25]. Strategies are formulated in order to achieve a more favourable position [26]. The implication of strategic management will result in organization gaining of competitive advantage.

As seen by some research, analysis of external factor and internal factor are crucial in the strategy making process [27][28][29][30]. Some of the external factors that used in previous research for example are: competition, economic impact, social cultural demographic, political, natural environment, technological change, trends, and market share.

Also, the internal factors that have to be considered are management team, organization structure and culture, distinctive competency, competitive advantage, operations, marketing, human resources, finance \& accounting, information tech/system, R\&D.

There are 11 alternative strategies that classified into 4 big clusters [31]: Integration, Intensive, Diversification, and Defensive. Those strategies listed in table II. Integration strategy allows a company to gain control over distributors, suppliers and even competitors. Intensive strategies consist of market penetration, market development, and product development. This kind of strategy requires intensive efforts.

Diversification strategies consist of two types: related and unrelated diversification. Defensive strategies consist of retrenchment, divestiture or liquidation.

\section{Methodology}

The first step is choosing the research object. The objects are six fashion start ups that meet the start up criteria and less than 5 years old. These companies are the companies that operate in male fashion business.

The first company is company A, a denim brand in Jakarta. This brand is targeting young male from 17-30 years old that has interest in denim .It consist of 2 owners and has no employee. All the process is managed by owner-manager. Since last year, this brand is also more focus market, the motorcycle rider community.

The second company is company $\mathrm{B}$, a brand that sold cheaper but still has good quality denim. This brand is more focus on the material than been used. The owner has special interest in material more than the design.

The third company is company $\mathrm{C}$, a street wear brand that sells male $\mathrm{t}$-shirt. This brand sells both online and in local retail in Indonesia. This brand sells to Jakarta, Solo, Jogja, Surabaya, Bali, Bandung, Lampung. This start up has 2 owner-manager and 5 employees. As the other start up company, this brand has informal structure, intuitive decision making. This brand is one of the senior among the fashion start up and ready to legalize its operation by changing into incorporated company.
Table 2: Types of strategy

\begin{tabular}{|c|c|c|}
\hline Cluster & Strategy & Definition \\
\hline \multirow[t]{3}{*}{ Integration } & $\begin{array}{l}\text { Forward } \\
\text { integration }\end{array}$ & $\begin{array}{l}\text { Gaining ownership of } \\
\text { Distributor/retailers. }\end{array}$ \\
\hline & $\begin{array}{l}\text { Backward } \\
\text { integration }\end{array}$ & Seeking ownership of suppliers \\
\hline & $\begin{array}{l}\text { Horizontal } \\
\text { integration }\end{array}$ & $\begin{array}{l}\text { Seeking ownership of competi- } \\
\text { tor }\end{array}$ \\
\hline \multirow[t]{3}{*}{ Intensive } & $\begin{array}{c}\text { Market } \\
\text { penetration }\end{array}$ & $\begin{array}{c}\text { Increase market share } \\
\text { throughmarketing efforts }\end{array}$ \\
\hline & $\begin{array}{c}\text { Market } \\
\text { development }\end{array}$ & $\begin{array}{c}\text { Expansion to new geographic } \\
\text { area }\end{array}$ \\
\hline & $\begin{array}{c}\text { Product } \\
\text { development }\end{array}$ & $\begin{array}{l}\text { Strategy that seeks increased } \\
\text { salesby improving or modify- } \\
\text { ing present products or services }\end{array}$ \\
\hline \multirow[t]{2}{*}{ Diversification } & $\begin{array}{c}\text { Related } \\
\text { Diversification }\end{array}$ & $\begin{array}{l}\text { Adding new related products } \\
\text { orservices }\end{array}$ \\
\hline & UnrelatedDiversification & $\begin{array}{l}\text { Adding new but unrelated } \\
\text { productsor services }\end{array}$ \\
\hline \multirow[t]{3}{*}{ Defensive } & Retrenchment & $\begin{array}{l}\text { Regrouping through cost and } \\
\text { assetreduction }\end{array}$ \\
\hline & Divestiture & Selling a division \\
\hline & Liquidation & Selling the whole company \\
\hline
\end{tabular}

The fourth company is company $\mathrm{D}$, the most senior brand among other start ups. The company's main product is denim, both make to order and make to stock. They are most widely known in young people in Jakarta. This brand is targeting the denim enthusiast, both new entry and old customer. The age range is 15-40 years.

The fifth company is company E. This brand was developed from online retail in 2013. The owners see the opportunity to create their own brand and they started to create their own fashion brand and sell their own T-shirt.

The sixth company is company $\mathrm{F}$, which sell the semi- formal shirt to more adult market.

The next step is setting the interview. The first part of the interview is more structured question to determine the identity and characteristics of the start up. The second part is to identify and explore the strategies that have been taken by the start up. In this part the respondent is asked about: how the company formulated the strategy, what kind of strategy that the company did, the outcome, and the things to be noted after implemented the strategy.

The method that has been used is qualitative interview. Qualitative interview is different from structured interview that used close ended question. The relationship during interview is not strictly scripted. Qualitative interview follows a conversational mode that leads to social relationship. Some advantages from using qualitative interview are there is an opportunity for two way interaction and better at understanding participant [32]

\section{Results and discussion}

Most of the objects use intuitive decision making. Only one of the objects is already use research to gather data from customer for decision making. Most of them just still use their feeling, intuition, and judgment based on current condition.

This is the result of the interview about the strategy that has been implicated by those fashion start ups.

\subsection{Company A}

The strategy that have been used in this company are

\section{- Market development}

This company sold its product to the store in Jogjakarta. Before that this company only focuses on Jakarta market because Jogjakarta was one of their highest sales from online store selling.

\section{- $\quad$ Product development}

This company develops the special product for motorcycle biker community with extra pocket to adjusting the customer needs.

\section{- Market penetration}

In order to support the previous product development strategy, this company increases the promotion to that special niche of customer 
through do promotion at the rider community event. One of the reasons is the motorcycle bikers are a tight community with a lot of community event that can be used for promotion of their product. This brand also has a motorcycle theme in instagram photo to emphasize this strategy.

\section{- Related diversification}

After success entering the new market, this brand realizes the need to sell the complementary fashion item that can be used by the biker community. This brand sold slayer, one of the items that frequently used by motorcycle rider and also made the canvas pants that can be used by motorcycle rider.

We can conclude from those explanations that most of the strategies that taken by company $\mathrm{A}$ is related one with each other.

\subsection{Company B}

The strategy that has been used by this brand is:

\section{- Product development.}

Company B develops and now focus on make to order concep that can reach people with different size. This has been the strength point for this brand. This company can guarantee that this company will make the denim with the right size for every customer. To support this strategy, this brand recruits two tailors that work especially for them. The key to this kind of strategy is to find the skilful tailor that can respond to customer demand. Because based on interview, doing make to order concept with outside/contract tailor is risky. The inventory issue must be noted. This strategy required quite big money capital for fashion start up company to buy the machine. Company B use outside money from investor to do this infestation to support the strategy.

\subsection{Company $C$}

Strategy that have been used in this brand are

\section{- $\quad$ Related Diversification}

This brand saw the growing of the young woman population that favour the street wear style. This brand produces street wear t-shirt for woman. But designing for women is quite different than designing for men. This brand recruits 1 special employee that design the women t-shirt. This design for women must keep the theme with the men design.

\section{- Market Penetration}

This brand did the collaboration with fashion account in social media instagram. It made some sort of a contest to promote their brand on instagram.

\section{- Market Development}

At first, this brand only sold online. But this brand tries to sell their product in local retail. The local retail industry is growing in Indonesia. After putting in their product on retail, this brand sold not only in Jakarta, but also in various cities in Indonesia. The thing to be noted is the market outside Jakarta is fragile to competition with international brand. One store in Medan was closed because the international brands penetrate their market.

\subsection{Company D}

The strategies that have been used by this brand are:

\section{- Market Penetration}

This brand use market penetration to acquire more market share. It uses social media as instagram. This brand also did a promotion in denim forum/community. This is an opportunity that can be used because the denim community have their own forum to share and promoting brand. This is when the power of mouth to mouth marketing can be used.

\section{- Market Development}

This brand began to promote their product in international community of denim enthusiast. This brand now starts selling into Thailand and even USA. This brand sells their product in retail in Thailand and reach US market via online shopping. This is a quite achievement for Indonesian denim brand. Once again the denim community forum played a vital part in this strategy

\section{- Product Development}

One of the uniqueness of this brand is that this brand is developing its own denim material. This brand makes a strategic alliance with a textile expert. This new material become their trademark and sold very well on the market.

Some things to be noted when trying to do this strategy are: the cost and the market. This strategy requires quite big money investment. Make sure the brand has its own niche of market before this do this action.

\section{- $\quad$ Related diversification}

Once this brand has already has its own name, they do diversification to product that comes together with denim as leather wallet and $\mathrm{t}$ shirt.

\subsection{Company $E$}

The strategy that has been used by this brand is:

\section{- Market Penetration}

This brand implemented the market penetration strategy. It gained new market the street art community. It has similar strategy and approach with company $\mathrm{F}$.

\subsection{Company $F$}

The strategy that has been used by this brand is:

\section{- $\quad$ Related Diversification}

This brand does related diversification by producing Muslim wear (koko) because of high population of Muslim in Indonesia. Therefore give them big market. This production is scheduled during the Ramadhan season.

Table 3: No. of strategy use

\begin{tabular}{|c|c|c|}
\multicolumn{1}{|c}{ Table 3: No. of strategy use } \\
\hline Cluster & Strategy & Number of Strategy Use \\
\hline Intensive & Marketpenetration & 4 \\
\hline & Marketdevelopment & 3 \\
\hline & Productdevelopment & 3 \\
\hline Diversification & RelatedDiversification & 4 \\
\hline
\end{tabular}

Table 4: Summary of strategies used

\begin{tabular}{|c|c|c|c|c|c|c|}
\hline Strategy & $\mathbf{A}$ & B & C & D & $\mathbf{E}$ & $\mathbf{F}$ \\
\hline $\begin{array}{c}\text { Market } \\
\text { Penetration }\end{array}$ & $\begin{array}{c}\text { Target- } \\
\text { ing } \\
\text { motor- } \\
\text { cycle } \\
\text { biker } \\
\text { commu- } \\
\text { nity via } \\
\text { promo- } \\
\text { tion } \\
\end{array}$ & & $\begin{array}{l}\text { Insta- } \\
\text { gram } \\
\text { contest }\end{array}$ & $\begin{array}{c}\text { Social } \\
\text { media } \\
\text { exten- } \\
\text { sive } \\
\text { promo- } \\
\text { tion }\end{array}$ & $\begin{array}{l}\text { Promo- } \\
\text { tion to } \\
\text { street art } \\
\text { commu- } \\
\text { nity }\end{array}$ & \\
\hline $\begin{array}{c}\text { Market } \\
\text { Develop- } \\
\text { ment }\end{array}$ & $\begin{array}{c}\text { New } \\
\text { market } \\
\text { geogra- } \\
\text { phy in } \\
\text { Jogja- } \\
\text { karta }\end{array}$ & & $\begin{array}{c}\text { Sold in } \\
\text { retail } \\
\text { outside } \\
\text { Jakarta. }\end{array}$ & $\begin{array}{c}\text { New } \\
\text { market } \\
\text { segment } \\
\text { in } \\
\text { Thai- } \\
\text { land } \\
\text { and } \\
\text { USA }\end{array}$ & & \\
\hline $\begin{array}{l}\text { Product } \\
\text { Develop- } \\
\text { ment }\end{array}$ & $\begin{array}{c}\text { Special } \\
\text { product } \\
\text { for } \\
\text { motor- } \\
\text { cycle } \\
\text { biker }\end{array}$ & $\begin{array}{l}\text { Custom- } \\
\text { ize } \\
\text { product } \\
\text { that can } \\
\text { reach } \\
\text { people } \\
\text { with } \\
\text { different } \\
\text { size } \\
\end{array}$ & & $\begin{array}{l}\text { New } \\
\text { material } \\
\text { research }\end{array}$ & & \\
\hline $\begin{array}{l}\text { Related } \\
\text { Diversifica- } \\
\quad \text { tion }\end{array}$ & $\begin{array}{l}\text { Produc- } \\
\text { tion of } \\
\text { canvas } \\
\text { pants } \\
\text { and } \\
\text { bandana }\end{array}$ & & $\begin{array}{c}\text { Pro- } \\
\text { duce } \\
\text { woman } \\
\text { t-shirt }\end{array}$ & $\begin{array}{l}\text { Leather } \\
\text { product }\end{array}$ & & $\begin{array}{c}\text { New } \\
\text { Prod- } \\
\text { uct: } \\
\text { Mus- } \\
\text { lim } \\
\text { Clothe } \\
\text { s }\end{array}$ \\
\hline
\end{tabular}




\section{Conclusion}

We summarize the number of strategy used in the object's start ups and summarize it in table III and table IV. We can see that most of fashion start ups in Indonesia use Intensive strategy: Market penetration, Market Development, and Product Development. In Market Penetration the media that use to increase awareness of the target market is instagram and through community or forum. Market development is an alternative because the growing of fashion enthusiast in other city than Jakarta. The growing of local brand retail is the opportunity to be exploited. The innovative product development can take quite big infestation, so make sure the start up has solid market to use.

\section{Acknowledgements}

The authors acknowledge the support of Universitas Indonesia through Hibah PITTA 2017.

\section{References}

[1] I.M Jawahar, G. McLaughlin, "Toward A Descriptive Stakeholder Theory: An Organizational Life Cycle Approach", Academy of Management Review; vol 26, no. 3, pp. 397-414, July 2001.

[2] B. Gurel, I.U Sari, "Strategic Planning for Sustainability in a StartUp Company: A Case Study on Human Resources Consulting Firm, European Journal of sustainable Development, vol. 4, no 2, pp.313322,2015

[3] S. Stubner, T. Wulf, H. Hungenberg, "Management Support and the Performance of Entrepreneurial Start-Ups - An Empirical Analysis Of Newly Founded Companies in Germany", Management Support, vol. 59, pp. 138-159, April 2007.

[4] P. Basu, S.K Nair, "Analyzing operational risk-reward trade-offs for start ups" European Journal of Operational Research, Vol. 247, pp. 596-609, 2015

[5] I, Suryani, "Fashion, Penguasa Bisnis Kreatif Kedua Indonesia", https://www.dream.co.id/dinar/-industri-fashion-peringkat-iidalam- perkembangan-di-badan-eko-1601133.html, May 5, 2017/

[6] J.P.T Fatt, Encouraging fashion entrepreneurship in Singapore, Asia Pasific Journal of Marketing and Logistics, Vol. 13, No. 1, pp.72-83, 2001.

[7] I.L Sugih, S. Soekarno, "Lesson Learned from Indonesian Biggest Fashion Retailer Company to Encourage the Development of Small Fashion Business", Procedia: Social and Behavioral Sciences, Vol. 169, pp. 240-248, 2015.

[8] C.M Moore, G. Birtwistle, "The Burberry business model: creating an international luxury fashion brand", International Journal of Retail \& Distribution Management; Vol.32, No.8/9, pp. 412-422, 2004

[9] M.B Diambeidou, B. Gailly, "A taxonomy of the early growth of Belgian start-ups", Journal of Small Business and Enterprise Development, Vol. 18, No.2, pp. 194-218, 2011

[10] B. Gurel, I.U Sari, "Strategic Planning for Sustainability in a StartUp Company: A Case Study on Human Resources Consulting Firm, European Journal of sustainable Development, vol. 4, no 2, pp.313$322,2015$.

[11] D.L Lester, J.A Parnell, W. Crandall, M. Menefee, "Organizational life cycle and performance among SMEs: Generic strategies for high and low performers", International Journal of commerce and Management, Vol. 18, No. 4, pp.313-330, 2008.

[12] R.E Quinn, K. Cameron, "Organizational life cycle and shifting criteria of effectiveness: Some preliminary evidence", Management Science, Vol. 29, No. 1, pp. 33-51, 1983.

[13] D. Miller, P.H Friesen, "A Longitudinal Study of the corporate life cycle", Management Science, Vol 30, No. 10, pp.1161-1183, 1984. [14]D.L Lester, J.A Parnell, W. Crandall, M. Menefee, “Organizational life cycle and performance among SMEs: Generic strategies for high and low performers", International Journal of commerce and Management, Vol. 18, No. 4, pp.313-330, 2008.

[15] M. Scott, R. Bruce, "Five Stages of Growth in Small Business", Long Range Planning, Vol. 20, No. 3, pp 45-52, 1987.

[16] R. Lipi, "The Growth Performance of Small Business under the View of Life-Cycle Model" Management Research and Practice, Vol. 5, No.4, pp-58-67, 2013.

[17] E.A Gurianova, I.N Gurianov, S.A Mechtcheriakova, "The Influence of Phase the Organizational Life Cycle on Organizational
Structure Management and Transaction Costs", Asian Social Science, Vol. 10, No. 20, pp. 137-142, 2014.

[18] D.L Lester, J.A Parnell, W. Crandall, M. Menefee, "Organizational life cycle and performance among SMEs: Generic strategies for high and low performers", International Journal of commerce and Management, Vol. 18, No. 4, pp.313-330, 2008

[19] S.P Robbins, D.A De Cenzo, M. A Coulter, "Fundamentals of Management: Essential Concepts and Applications, 8th ed, Pearson, 2013, pp.112-116.

[20] R.G.P McMahon, "Ownership structure business growth and financial performance amongst SMEs; From Australia's business longitudinal survey", Journal of Small Business and Enterprise Development, Vol. 14, No. 3, pp 458-477, 2007.

[21] C.L Escalante, C.G Turvey, "Business start-up survival challenges and strategies of Agribusiness and non-agribusiness entrepreneurs", Agricultural Finance Review, Vo.66, No. 1, pp-61-75, 2006.

[22] D.L Lester, J.A Parnell, W. Crandall, M. Menefee, "Organizational life cycle and performance among SMEs: Generic strategies for high and low performers", International Journal of commerce and Management, Vol. 18, No. 4, pp.313-330, 2008.

[23] M. Scott, R. Bruce, "Five Stages of Growth in Small Business", Long Range Planning, Vol 20, No. 3, pp 45-52, 1987.

[24] A.M Hormozi, G.S. Sutton, R.D McMinn, W. Lucio, "Business plans for new or small businesses: paving the path to success", Management Decision, Vol. 40, pp. 755 - 763, 2002.

[25] B. Kim, "Competitive priorities and supply chain strategy in the fashion industry", Qualitative Market Research: An International Journal, Vol. 16, No. 2, pp. 214-242, 2013.

[26] R. Feurer, K. Chaharbaghi, "Strategy formulation: a learning methodology", Benchmarking for Quality Management \& Technology, Vol. 2, No. 1, pp 38-55, 1995

[27] F.R David Strategic Management: Concept and Cases, 13th ed, Prentice Hall, 2009, pp.9

[28] B. Gurel, I.U Sari, "Strategic Planning for Sustainability in a StartUp Company: A Case Study on Human Resources Consulting Firm, European Journal of sustainable Development, vol. 4, no 2, pp.313$322,2015$.

[29] A.R Ommani, "Strengths, weakness, opportunities, and threats (SWOT) analysis for farming system businesses management: Case of wheat farmers of Shardervan district, Soushtar Township, Iran", African Journal of Business Management, Vol.5, No 22, pp9448-9535, 2011.

[30] R.R dos Santos, F.J.C de melo Melo, C.N de Queiroz Claudino, D.D de Medeiros, "Model for formulating competitive strategy: the supplementary health sector case", "Model for formulating competitive strategy: the supplementary health sector case", Benchmarking: An International Journal, Vol. 24, No. 1, pp 219-243, 2017

[31] F.R David Strategic Management: Concept and Cases, 13th ed, Prentice Hall, 2009, pp. 136 - 151

[32] R.K. Yin, "Qualitative Research from Start to Finish", 2011, The Guilford Press, pp.132-135. 